UDC 622.553.982.2

Article / Статья

(C) PNRPU / ПНИПУ, 2020

\title{
Refining Permeability Values for History-Matching of the Reservoir Simulation Model
}

\section{Margarita A. Smetkina ${ }^{1}$, Oleg A. Melkishev ${ }^{1}$, Maksim A. Prisyazhnyuk ${ }^{2}$}

${ }^{1}$ Perm National Research Polytechnic University (29 Komsomolskiy ave., Perm, 614990, Russian Federation) ${ }^{2}$ PermNIPIneft branch of LUKOIL-Engineering LLC in Perm (3a Permskaya st., Perm, 614015, Russian Federation)

\section{Уточнение значений проницаемости при адаптации гидродинамической модели}

\section{М.А. Сметкина ${ }^{1}$, О.А. Мелкишев ${ }^{1}$, М.А. Присяжнюк ${ }^{2}$}

${ }^{1}$ Пермский национальный исследовательский политехнический университет (Россия, 614990, г. Пермь, Комсомольский пр., 29) ${ }^{2}$ Филиал ООО «ЛУКОЙЛ-Инжиниринг» «ермНИПИнефть» в г. Перми (Россия, 614000, г. Пермь, ул. Пермская, За)

\section{Received / Получена: 21.02.2020. Accepted / Принята: 15.06.2020. Published/ Опубликована: 17.08.2020}

Keywords:

reservoir simulation model, permeability, initial permeability, adjusted permeability, porosity, geological model, upscaling, well log interpretation results, geological and physical attributes, statistical characteristics, permeability cube, development indicators. history-matching, porosity and cube, core, modified permeability

Reservoir simulation models are used to design oil field developments, estimate efficiency of geological and engineering operations and perform prediction calculations of long-term development performances. A method has been developed to adjust the permeability cube values during reservoir model history-matching subject to the corederived dependence between rock petrophysical properties. The method was implemented using an example of the Bobrikovian formation (terrigenous reservoir) deposit of a field in the Solikamskian depression. A statistical analysis of the Bobrikovian formation porosity and permeability properties was conducted following the well logging results interpretation and reservoir modelling data. We analysed differences between the initial permeability obtained after upscaling the geological model and permeability obtained after the reservoir model history-matching. The analysis revealed divergences between the statistical characteristics of the permeability values based on the well logging data interpretation and the reservoir model, as well as substantial differences between the adjusted and initial permeability cubes. It was established that the initial permeability was significantly modified by manual adjustments in the process of history-matching. Extreme permeability values were defined and corrected based on the core-derived petrophysical dependence $K P R=f(K P)$, subject to ranges of porosity and permeability ratios. By using the modified permeability cube, calculations were performed to reproduce the formation production history. According to the calculation results, we achieved convergence with the actual data, while deviations were in line with the accuracy requirements to the model history-matching. Thus, this method of the permeability cube adjustment following the manual history-matching will save from the gross overestimation or underestimation of permeability in reservoir model cells.

Ключевые слова: гидродинамическая модель, адаптация, фильтрационноемкостные свойства, исходная проницаемость, адаптированная проницаемость, пористость, геологическая модель, ремасштабирование результаты интерпретации геофизических исследований скважин, геолого-физические характеристики, статистические

характеристики, куб проницаемости, керн, модифицированный куб проницаемости, показатели разработки.
Гидродинамическая модель (ГДМ) является инструментом для проектирования разработки нефтяных месторождений, расчета эффективности геолого-технических мероприятий (ГТМ) и выполнения прогнозных расчетов показателей разработки на долгосрочный период времени. Разработан метод корректирования значений куба проницаемости в процессе адаптации ГДМ с учетом зависимости между петрофизическими свойствами пород по данным исследования керна. Методика реализована на примере залежи бобриковского пласта (терригенный коллектор) одного из месторождений Соликамской депрессии. Проведен статистический анализ фильтрационно-емкостных свойств бобриковского пласта по результатам интерпретации геофизических исследований скважин и по данным гдМ; рассмотрены различия между исходной проницаемостью, полученной после ремасштабирования геологической модели, и проницаемостью после адаптации ГДМ. В результате проведенного анализа выявлены несоответствия в статистических характеристиках значений проницаемости по данным интерпретации геофизических исследований скважин и в ГдМ, а также существенные различия кубов адаптированной и исходной проницаемости. Установлено, что в процессе настройки модели значительно модифицирована исходная проницаемость методом «ручной» адаптации. Выявление и корректировка экстремальных значений проницаемости выполнены на основе петрофизической зависимости $K P R=f(K P)$ по керну с учетом диапазонов изменения коэффициентов пористости и проницаемости. С применением модифицированного куба проницаемости выполнены расчеты по воспроизведению истории разработки объекта. По итогам расчетов достигнута сходимость с фактическими данными, отклонения соответствуют требованиям точности настройки модели. Таким образом, данный способ корректирования куба проницаемости после «ручной» адаптации модели позволит избежать значительных завышений или занижений проницаемости в ячейках ГДМ.

Margarita A. Smetkina - Assistant at the Department of Geology of Oil and Gas (tel.: + 00734221984 11, e-mail: rsmet@mail.ru).

Oleg A. Melkishev (Author ID in Scopus: 55531674700) - PhD, Associate Professor at the Department of Geology of Oil and Gas (tel.: +007 342 219 84 11, e-mail: melkishev@pstu.ru). The contact person for correspondence.

Maksim A. Prisyazhnyuk (Author ID in Scopus: 56979292200) - Head of the Department for Creation and Monitoring of Hydrodynamic Models (tel.: + 007342236403 , e-mail: Maksim.Prisyazhnyuk@pnn.lukoil.com).

Сметкина Маргарита Андреевна - ассистент кафедры геологии нефти и газа (тел.: + 00734221984 11, e-mail: rsmet@mail.ru)

Мелкишев Олег Александрович - кандидат технических наук, доцент кафедры геологии нефти и газа (тел.: +007 342 219 84 11, e-mail: melkishev@pstu.ru). Контактное лицо для переписки.

Присяжнюк Максим Александрович - начальник отдела создания и мониторинга гидродинамических моделей (тел.: +007 342236403 , е-таil: Маksim. Prisyazhnyuk@pnn.lukoil.com). 


\section{Introduction}

Presently, oil and gas field developments are supported by geological and reservoir simulations of the deposits. A geological model that characterises a deposit geology and distribution of oil and gas reserves serves as a basis for building reservoir simulation models [1-7]. Development of a fluid-flow simulation model generally starts with its geological model upscaling, which results in the transfer of parameters (porosity, permeability, saturation) to an enlarged grid while retaining the formation vertical heterogeneity [8-10]. Following the upscaling procedure, the data on fluid properties [11-13], relative permeability, capillary forces and transition zone model [14-22] are prepared to set the initial state of the reservoir model [23]. After the historical data of the well operation have been prepared, the field development history-matching and the adjustment of the development parameters are performed [24-28]. In the process of the reservoir model history-matching, the impact of the aquifer is refined, permeability in the aquifer and within the oil zone, as well as relative permeability are corrected; the well productivity and injectivity indices are adjusted (the values of skin factor and reservoir-to-well connectivity) $[29,30]$.

In the model development process, the formation geological and physical attributes, permeability, relative permeability curves, etc. can be refined. [31]. The above parameters are determined using the core study and well logging data [32], as well as well testing methods [33-36]. That being said, the obtained information on reservoir properties is quite limited, while uncertainty in the porosity and permeability values distribution increases with each stage of the model development. Firstly, it happens when averaging the well data to the geological model grid cells and interpolating the measurement data in the interwell space. Secondly, it takes place upon upscaling of the geological model. Thirdly, it is true for the process of the reservoir model history-matching.

The initial permeability (obtained upon the geological model upscaling) can be significantly modified, as the fluid flow distribution in the model and, therefore, the dynamics of the development indicators depend on this parameter value.

Given that the initial permeability adjustment, as well as the reservoir model history-matching are manually performed, the problem of retaining the distribution features of the reservoir initial geological and physical attributes and preventing incorrect porosity and permeability values in the cubes is arising.

Thus, the quality of the reservoir model history-matching [37-39] determines the efficiency of its application for predicting the development indicators and efficient designing of geological and engineering operations [40-43]. The crucial task is to elaborate a standardised approach to permeability adjustment in the process of the reservoir model history-matching [44-46]. Let us consider the problem using the Bobrikovian formation (terrigenous reservoir) deposit of a field in the Solikamskian depression as an example. The reservoir model of the formation is a model of a three-phase isothermal fluid flow in a pore medium (terrigenous reservoir). To identify the basic regularities, the heterogeneity of reservoir properties in the Bobrikovian formation was analysed based on the results of the well log data interpretation, and differences in the permeability cubes were revealed in the upscaled geological model and history-matched reservoir model. Based on the core-driven dependence of permeability on porosity, the permeability cube was modified after manual adjustments, and the reservoir-model calculations of the Bobrikovian formation development indicators were performed.

\section{Statistical Characteristics of Reservoir Properties of the Bobrikovian Formation Based on the Well Log Interpretation Data}

The reservoirs in the Bobrikovian formation are sandstone and siltstone. To assess reservoir properties and heterogeneity of the formation, the following parameters were analysed based on the well $\log$ interpretation data: $K P$ is the porosity ratio, u.f.; $K P R$ is the permeability ratio, $\mathrm{mD} ; H_{-} P R$ is the thickness of the permeable interlayer, $\mathrm{m}$.

Table 1 gives the key statistical characteristics of the parameters.

Table 1

Key statistical characteristics of the parameters based on the well log interpretation data

\begin{tabular}{ccccccc}
\hline Parameter & $\begin{array}{c}\text { Average } \\
\text { value }\end{array}$ & Median & Mode & $\begin{array}{c}\text { Min. } \\
\text { value }\end{array}$ & $\begin{array}{c}\text { Max. } \\
\text { value }\end{array}$ & $\begin{array}{c}\text { Standard } \\
\text { deviation }\end{array}$ \\
\hline$K P$, u.f. & 0.1502 & 0.15 & 0.15 & 0.077 & 0.251 & 0.031 \\
\hline$K P R, \mathrm{mD}$ & 254.974 & 85.1 & 85.1 & 2.3 & $\begin{array}{c}4,428 . \\
5\end{array}$ & 485.403 \\
\hline$H_{-} P R, \mathrm{~m}$ & 1.796 & 1.4 & 0.8 & 0.1 & 12.9 & 1.4667 \\
\hline
\end{tabular}


Out of the entire sample array (for 327 wells), more than a half of the porosity ratio values falls between 0.13 and 0.18 u.f., and only very few values are below 0.08 and above 0.25 u.f. The average porosity value is 0.15 u.f. In the most cases (94 \%), the permeability ratio varies between 2.3 and $1000 \mathrm{mD}$, while in $70 \%$ of the cases, the permeability does not exceed $200 \mathrm{mD}$. The average permeable interlayer thickness is $1.8 \mathrm{~m}$.

Based on the well log interpretation data analysis, it has been established that the Bobrikovian formation reservoirs are generally classified as medium porosity and permeability reservoirs as per A.A. Khanin classification (class III: porosity $11-18 \%$, permeability 100-500 mD; class IV: porosity 10-16.8 \%, permeability 1-100 mD).

\section{Statistical Characteristics of Reservoir Properties of the Bobrikovian Formation in the Reservoir Model}

To compare the porosity and permeability values of the Bobrikovian formation based on the well $\log$ interpretation data and the reservoir model, an analysis of porosity and permeability in the reservoir model containing 423,150 cells was performed. The key statistical characteristics for the cubes were determined: porosity (PORO), initial permeability after the geological model upscaling (PERMX_ish) and permeability in the history-matched reservoir model (PERMX_adapt). Table 2 shows the key statistical characteristics of porosity and permeability in the model.

The distributions of the porosity ratio values based on the well log interpretation data and the reservoir model are generally similar, with an average value of 0.15 u.f., permeability not exceeding $200 \mathrm{mD}$ in most cases (80-90\%), for the initial and adjusted permeability cube.

During the reservoir model history-matching of the Bobrikovian formation, the initial permeability value has been adjusted to obtain the development estimates as close to the actual values as possible. The data in Table 2 shows that the permeability in the adjusted cube is generally lower than in the initial cube upon upscaling of the geological model.

A difference cube (PERMX_delta) and a multiplier cube (PERMX_k) were computed to determine the degree of difference between permeability in the history-matched reservoir model and in the upscaled geological model:

\section{PERMX_delta $=$ PERMX_adapt - PERMX_ish, PERMX_k = PERMX_adapt $/$ PERMX_ish.}

Table 2

Key statistical characteristics of porosity and permeability of the reservoir simulation model

\begin{tabular}{ccccc}
\hline Parameter & $\begin{array}{c}\text { Average } \\
\text { value }\end{array}$ & Min. value & $\begin{array}{c}\text { Max. } \\
\text { value }\end{array}$ & $\begin{array}{c}\text { Standard } \\
\text { deviation }\end{array}$ \\
\hline PORO, u.f. & 0.147 & 0.079 & 0.2483 & 0.0218 \\
\hline PERMX_ish, $\mathrm{mD}$ & 157.375 & 2.311 & $9,771.3$ & 246.013 \\
\hline PERMX_adapt, $\mathrm{mD}$ & 114.066 & 0.025 & $1,719.0$ & 222.756 \\
\hline PERMX_delta, $\mathrm{mD}$ & -43.310 & $-9,738.5$ & $1,716.39$ & 325.432 \\
\hline PERMX_k, u.f. & 2.172 & $4.925 \cdot 10^{-5}$ & 743.743 & 12.124 \\
\hline PERMX_petro, $\mathrm{mD}$ & 115.982 & 0.150 & $1,719.0$ & 211.47 \\
\hline
\end{tabular}

The difference between the adjusted and initial permeability (PERMX delta) varies from $9,738.5$ to $1,716.39 \mathrm{mD}$, while the average value is shifted to negative values (see Table 2). It was determined that in $70.2 \%$ of cases, PERMX_delta $<$ $<0 \mathrm{mD}$, i.e. the adjusted permeability is less than the initial value; in $29 \%$ of the cases, PERMX_delta $>0 \mathrm{mD}$, i.e. the adjusted permeability is greater than the initial value; and in $0.8 \%$ of the cases, the permeability in the reservoir model is equal to the initial value.

In most cases ( $80 \%)$, the permeability in the history-matched model differs from the initial value by an amount from -220 to $+110 \mathrm{mD}$. The permeability multiplier distribution (PERMX_k) is close to the exponential distribution, the median being equal to 0.367 u.f.

Thus, when comparing the results of the parameter analysis from the well log interpretation data and the reservoir model in general, a consistency in the statistical characteristics of distributions of the porosity values was determined, while the distributions of the permeability values exhibit differences. The average permeability value based on the well log interpretation data is generally higher than that in the models upon upscaling and history-matching (parameter values are 254.974, 157.375 and $114.066 \mathrm{mD}$, respectively).

\section{Adjustment of Permeability Ratio in the Reservoir Model}

The option of adjusting the permeability values in the history-matched model as per porosity ratio ranges based on empirical data was considered. For this purpose, the core-derived petrophysical dependence $K P R=f(K P)$ was broken down into intervals by porosity, each of 
them corresponding to a certain range of permeability variation (Fig. 1).

From the initial field of values shown in Figure 1, the area with the highest data point density was selected, while single anomalous values outside the selected area were disregarded, as the modelling used averaged data. Four porosity ranges (I-IV) were determined; for each of them boundary values of permeability were set by equations (solid green lines in Fig. 1). The designated boundaries are outlier-independent, which results in a smoother permeability cube.

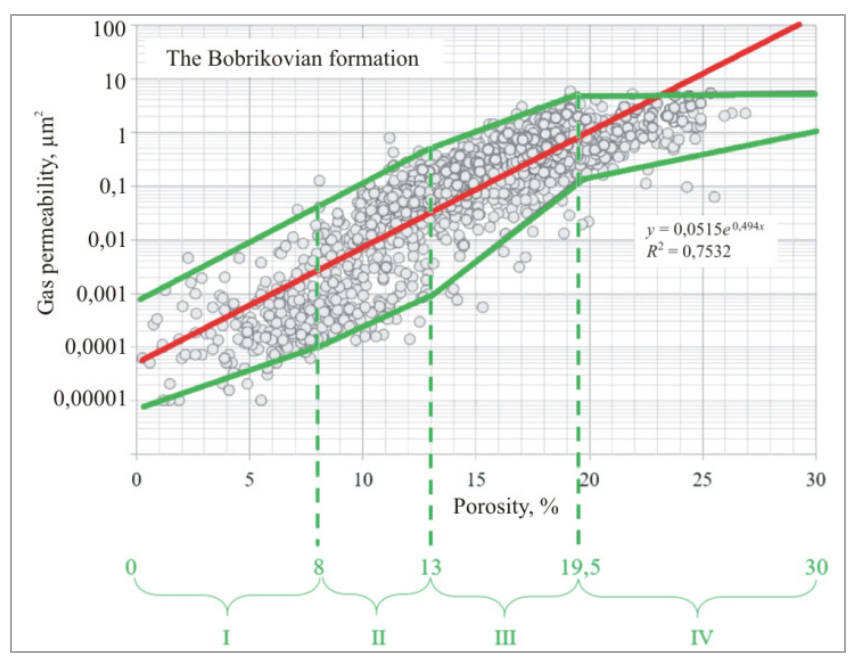

Fig. 1. Core-derived dependence of permeability on porosity

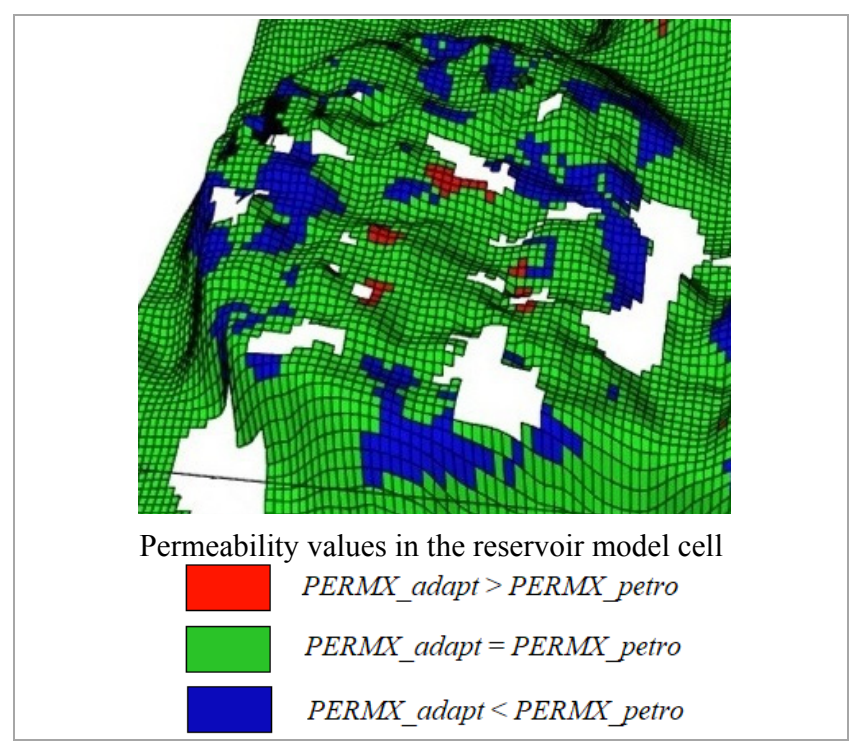

Fig. 2. The cube representing the permeability deviation from the petrophysical dependence in the history-matched model

The method of the adjusted permeability cube correction consists in checking whether the adjusted permeability value falls within the specified boundaries, depending on the porosity value in the reservoir model cell. If the permeability value in the reservoir model cell is outside the given boundaries, it is assigned an upper or lower boundary value of the permeability ratio, which depends on the porosity. Such an approach to the adjusted permeability cubes eliminates the gross overestimation and underestimation of the permeability ratio in the reservoir model cells.

This approach stands on the fact that the core data scale is in centimetres, and the cell size in the reservoir model is $25 \times 25$ metres. Therefore, the core-derived permeability values cannot be fully assigned to the model cell, especially in the area of the high permeability ratio values.

Using the permeability boundary values, a permeability cube (PERMX_petro) was obtained and adjusted based on the cube after the manual historymatching of the model (PERMX_adapt). The resulting modified permeability cube (PERMX_petro) in the oil-water boundary has deviations corresponding to those from the petrophysical dependence. In the calculations, the aquifer permeability is set as equal to that in the adjusted cube to exclude the effect of various aquifer settings on the calculation results. In Figure 2, red and blue colours designate anomalous high and low permeability values in the history-matched reservoir model, which outline the boundaries of the main data point cloud for the dependence of permeability on porosity (see Fig. 1).

Table 2 shows the key statistical characteristics for the permeability cube (PERMX_petro) modified according to the petrophysical dependence. The data in Table 2 show that in the adjusted cube, the lower permeability boundary is $0.025 \mathrm{mD}$ (PERMX_adapt cube), and after the exclusion of anomalous values by the proposed method, it was raised to $0.15 \mathrm{mD}$ (PERMX_petro cube), with the upper boundary of $1,719 \mathrm{mD}$ remaining unchanged and the average values almost identical.

For comparison, development indicators were calculated using the permeability cubes from Table 1 (PERMX_ish, PERMX_adapt, PERMX_petro). For the initial and modified permeability cubes, the oil and liquid production performance based on the computation results coincides with the actual performance - both for field domes individually and for the formation in general. The greatest convergence with the historical data was obtained at the initial development period. Figure 3 shows deviations in the calculation results from the actual 
data for cumulative oil production, cumulative liquid production and watercut of the formation over the entire development period.

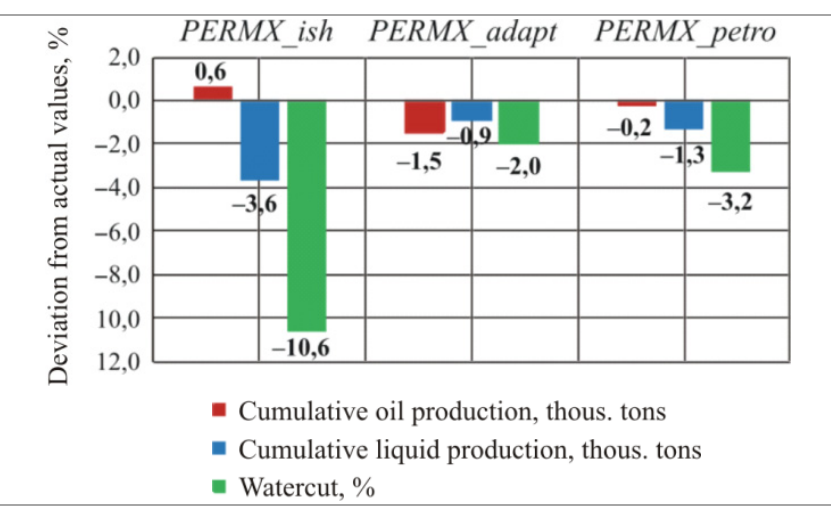

Fig. 3. Results of the reservoir model calculations for the productive formation in general over the entire development period

Figure 3 shows that the greatest convergence with the actual performance was achieved through the manual history-matching of the model (PERMX adapt cube). When the permeability cube was adjusted to the core to core petrophysical dependence, the deviations from the actual performance were also consistent with the accuracy requirements to the model history-matching (PERMX_petro cube), the deviation in the cumulative oil production was reduced therewith.

\section{Conclusions}

1. From the data analysis of the well $\log$ interpretation and the reservoir model, it was established that in most cases the Bobrikovian formation permeability does not exceed $200 \mathrm{mD}$.

2 . In the history-matched reservoir model, the initial permeability obtained after the upscale of the geological model was adjusted in most cases by an amount from -220 to $+110 \mathrm{mD}$.

3. The approach under consideration provides for permeability adjustment after the manual history-matching of the model subject to the porosity ranges based on core-derived dependence $K P R=f(K P)$. The result is the adjusted permeability cube PERMX_petro excluding gross overestimations and underestimations in the reservoir model cells.

4. A convergence of the development indicators with the actual data was achieved as a result of the calculations in the history-matching of the Bobrikovian formation development using the adjusted cube. This approach resulted in the deviation from the actual performance in the cumulative oil production of 0.2 thousand tons, the cumulative liquid production of 1.3 thousand tons, and watercut of $3.2 \%$, which is in line with the model history-matching requirements.

\section{References}

1. Potekhin D.V., Putilov I.S., Galkin V.I. Povyshenie dostovernosti geologicheskikh modelei zalezhei nefti i gaza na osnove usovershenstvovannoi tekhnologii mnogovariantnogo trekhmernogo modelirovaniia [Improve the reliability of geological models of oil fields on basis of optimized technological settings multivariate 3D modeling]. Neftianoe khoziaistvo, 2014, no. 6 , pp. 16-19.

2. Putilov I.S., Potekhin D.V. Razrabotka metodiki mnogovariantnogo 3D-modelirovaniia s kontrolem kachestva realizatsii dlia povysheniia dostovernosti geologicheskikh modelei [Creating technological polivariation 3D modeling with quality control of the models realization for raising reliability]. Neftianoe khoziaistvo, 2015, no. 1, pp. 15-17.

3. Wellmann F., Caumon G. Chapter One - 3D Structural geological models: Concepts, methods, and uncertainties. Advances in Geophysics, 2018, 121 p. DOI: 10.1016/bs.agph.2018.09.001

4. Getman A.V., Kiselev V.L., Alekseev A.S., Volkov V.P., Ishmuratov I.F. Voprosy kachestvennoi otsenki geologicheskoi modeli [Some problems of geological model qualitative assessment]. Neftianoe khoziaistvo, 2013, no. 11, pp. 90-93.

5. Yan-lin S., Ai-ling Z., You-bin H., Ke-yan X. 3D Geological Modeling and Its Application under Complex Geological Conditions. Procedia Engineering, 2011, vol. 12, pp. 41-46. DOI: 10.1016/j.proeng.2011.05.008

6. Muzik J., Vondráčková T., Sitányiová D., Plachý J., Nývlt V. Creation of 3D Geological Models Using Interpolation Methods for Numerical Modelling. Procedia Earth and Planetary Science, 2015, vol. 15, pp. 25-30. DOI: 10.1016/j.proeps.2015.08.007

7. Xuequn T., Yunyan L., Xiaozhou Z., Jiandang L., Rongchen Z., Chao J. Multi-parameter quantitative assessment of 3D geological models for complex fault-block oil reservoirs. Petroleum Exploration and Development, 2019, vol. 46, iss. 1, pp. 194-204. DOI: 10.1016/S1876-3804(19)30019-9

8. Carmichael T., Ailleres L. Method and analysis for the upscaling of structural data // Journal of Structural Geology, 2016, vol. 83, pp. 121-133. DOI: 10.1016/j.jsg.2015.09.002

9. Sharifia M., Kelkar M. Novel permeability upscaling method using Fast Marching Method. Fuel, 2014, vol. 117, part A, pp. 568-578. DOI: $10.1016 /$ j.fuel.2013.08.084

10. Koliagin A.G., Terent'ev V.L., Shevchenko E.I., Denisov V.V., Fedorov K.M. Snizhenie razmernosti modelei mnogoplastovykh zalezhei s sokhraneniem ikh geologicheskikh osobennostei [Reduction of model dimention retaining field geological features]. Neftianoe khoziaistvo, 2013, no. 9, pp. 40-43.

11. Lobanova O.A., Indrupskii I.M. Neravnovesnye i masshtabnye effekty $\mathrm{v}$ modelirovanii fazovogo povedeniia uglevodorodnykh smesei [Non-equilibrium and scale effects in modeling phase behavior of hydrocarbon mixtures]. Neftianoe khoziaistvo, 2012, no 6, pp. 49-53.

12. Amirsardari M., Dabir B., Naderifar A. Development of a flow based dynamic gridding approach for fluid flow modeling in heterogeneous reservoirs. Journal of Natural Gas Science and Engineering, 2016, vol. 31, pp. 715-729. DOI: 10.1016/j.jngse.2016.03.077

13. Efimov D.V., Savichev V.I. Opyt prakticheskogo modelirovaniia svoistv plastovykh fliuidov: ot standartnykh korreliatsii $\mathrm{k}$ kompozitsionnym termodinamicheskim modeliam [Reservoir fluids applied modeling: from correlations to compositional thermodynamic models]. Neftianoe khoziaistvo, 2012, no. 4, pp. 56-59. 
14. Pedersen K., Christensen P., Shaikh J. Phase Behavior of Petroleum Reservoir Fluid. Boca Raton: CRC Press, 2007, 465 p.

15. Ovcharov V.V. Modifikatsiia funktsii otnositel'nykh fazovykh pronitsaemostei dlia reguliarizatsii chislennogo resheniia zadachi vytesneniia nefti vodoi [Scaling of relative permeability functions as a method of regularizing numerical solution of the water-oil displacement problem]. Neftianoe khoziaistvo, 2014, no. 3 , pp. $102-105$.

16. Pereira G.G. Fluid flow, relative permeabilities and capillary pressure curves through heterogeneous porous media. Applied Mathematical Modelling, 2019, vol. 75, pp. 481-493. DOI: 10.1016/j.apm.2019.05.050

17. Stepanov S.V., Glumov D.N. Otsenka vliianiia razlichnykh podkhodov $\mathrm{k}$ obosnovaniiu nachal'nogo raspredeleniia fliuidov $\mathrm{i} i \mathrm{kh}$ podvizhnosti na rezul'taty gidrodinamicheskogo modelirovaniia [Impact evaluation of various approaches for justification of initial distribution of fluids and their mobility on the results of reservoir simulation modeling]. Neftianoe khoziaistvo, 2013, no. 12, pp. 112-116.

18. Wang S., Yu C., Sang G., Zhao Q. A new numerical simulator considering the effect of enhanced liquid on relative permeability. Journal of Petroleum Science and Engineering, 2019, vol. 177, pp. 282-294. DOI: 10.1016/j.petrol.2019.02.053

19. Svalov A.M. Analiz problem postroeniia krivykh kapilliarnogo davleniia pri modelirovanii plastovykh protsessov [Analysing problems of capillary pressure curves definition at modelling of formation processes]. Neftianoe khoziaistvo, 2015, no. 5 , pp. 70-73.

20. Nekrasov A.S., Potekhin D.V., Shilov A.V., Gabnasyrov A.V., Prisiazhniuk M.A. Obosnovanie izmeneniia vodonasyshchennosti po vysote zalezhi nefti i gaza pri geologo-gidrodinamicheskom modelirovanii [Substantiation of water saturation variations by height of oil and gas reservoir for the purposes of its geological and hydrodynamic modeling]. Neftianoe khoziaistvo, 2015, no. 10 , pp. $78-81$.

21. Jing-qiang L., Chao-mo Z., Zhansong Z. Combine the capillary pressure curve data with the porosity to improve the prediction precision of permeability of sandstone reservoir. Journal of Petroleum Science and Engineering, 2016, vol. 139, pp. 43-48. DOI: 10.1016/j.petrol.2015.12.018

22. Single-and two-phase flow model in low-permeability reservoir / S. Fuquan, S. Xingxing, W. Yong, S. Yeheng. Petroleum, 2019, vol. 5, iss. 2, pp. 183-190. DOI: $10.1016 /$ j.petlm.2018.05.004

23. Sazonov E.O., Nugaeva A.N., Cherviakova A.N. Novye podkhody $\mathrm{k}$ ravnovesnoi initsializatsii modeli BlackOil $\mathrm{i}$ obosnovaniiu urovnei zerkala svobodnoi vody i poverkhnosti vodoneftianogo kontakta [New approaches to equilibrium initialization of the Blackoil model and free water level evaluation]. Neftianoe khoziaistvo, 2018, no. 6, pp. 70-75. DOI: $10.24887 / 0028-2448-2018-6-70-75$

24. Cheremisin N.A., Bikbulatova T.G., Eletskii S.V. Apriornyi podkhod $\mathrm{k}$ otsenke vozmozhnosti ispol'zovaniia gidrodinamicheskikh modelei na praktike pri izvestnykh oshibkakh $\mathrm{v}$ zadanii nachal'nykh dannykh [The a priori approach to assessment of the hydrodynamic models in practice by known errors in the initial data]. Neftianoe khoziaistvo, 2013, no. 10, pp. 57-61.

25. Zakrevskii K.E., Arzhilovskii A.V., Timchuk A.S., Grishchenko M.A., Bikbulatova T.G. Povyshenie kachestva geologo-gidrodinamicheskogo modelirovaniia [Geological and hydrodynamic modeling quality improvement]. Neftianoe khoziaistvo, 2012, no. 10, pp. 44-48.

26. Denisov V.V., Zhivchuk M.V. Ekspress-otsenka neviazki i uskorenie nastroiki gidrodinamicheskoi modeli [Rapid assessment of discrepancy and acceleration of history matching in hydrodynamic model]. Neftianoe khoziaistvo, 2018, no. 11, pp. 100-101. DOI: 10.24887/0028-2448-2018-11-100-101

27. Spilsbury-Schakel J.A. Quality control of static reservoir models. SPE Asia Pacific Oil \& Gas Conference and
Exhibition, 11-13 September, Adelaide, Australia, 2006. DOI: $10.2118 / 101875-M S$

28. Taraskin E.N., Gutman I.S., Rudnev S.A., Zakharian A.Z., Ursegov S.O. Novyi adaptivnyi podkhod $k$ geologogidrodinamicheskomu modelirovaniiu dlitel'no razrabatyvaemykh mestorozhdenii i zalezhei [New adaptive approach to geological and hydrodynamic modeling of fields and reservoirs with long production history]. Neftianoe khoziaistvo, 2017, no. 6, pp. 78-83. DOI: $10.24887 / 0028-2448-2017-6-78-83$

29. Ibatullin R.R., Bakirov I.M., Nasybullin A.V., Antonov O.G., Rakhmanov A.R. Sozdanie i ispol'zovanie postoianno deistvuiushchei geologo-tekhnologicheskoi modeli 3 bloka Berezovskoi ploshchadi [Development and application of permanently updated geological and reservoir model for the third block of the Berezovskaya area]. Neftianoe khoziaistvo, 2012, no. 2, pp. 54-56.

30. Upton K.A., Butler A.P., Jackson C.R., Mansour M. Modelling boreholes in complex heterogeneous aquifers. Environmental Modelling \& Software, 2019, vol. 118, pp. 48-60. DOI: 10.1016/j.envsoft.2019.03.018

31. Zakirov E.S., Shiriaev I.M., Indrupskii I.M., Liubimova O.V. O vozmozhnosti geologicheski soglasovannogo utochneniia parametrov gazogidrodinamicheskoi modeli $\mathrm{v}$ mezhskvazhinnom prostranstve po dannym ekspluatatsii skvazhin [Possibility of geologically-coordinated specification of a gas-hydrodynamic model parameters in the inter-well space by wells operation data]. Geologiia, geofizika i razrabotka neftianykh $i$ gazovykh mestorozhdenii, 2016, no. 12, pp. 33-40.

32. Magdeev M.Sh., Fedotov M.V., Maslov S.A., Nazarov A.A. Tekhnologiia podgotovki, khraneniia i sovmestnogo analiza informatsii dlia sozdaniia kompleksnykh geologogidrodinamicheskikh modelei ob"ektov razrabotki neftianykh mestorozhdenii [The technology of preparation, storage and joint analysis of information applied to build complex geologicalhydrodynamic models for oil fields development]. Geologiia, geofizika $i$ razrabotka neftianykh $i$ gazovykh mestorozhdenii, 2017, no. 10 , pp. 17-22.

33. Mikhailov N.N. Novye napravleniia povysheniia informativnosti geologo-gidrodinamicheskogo modelirovaniia zalezhi [New lines of the raising of an informativity of geological and hydrodynamic deposit simulation]. Neftianoe khoziaistvo, 2013, no. 3, p. 69-73.

34. Latysheva M.V., Ustinova Iu.V., Kashevarova V.V., Potekhin D.V. Povyshenie effektivnosti gidrodinamicheskogo modelirovaniia posredstvom primeneniia usovershenstvovannykh metodik obrabotki dannykh gidrodinamicheskikh issledovanii skvazhin (na primere Ozernogo mestorozhdeniia) [Improvement of hydrodynamic simulation using advanced techniques of hydrodynamic well data processing (exemplified by Ozernoe field)]. Vestnik Permskogo natsional'nogo issledovatel'skogo politekhnicheskogo universiteta. Geologiia. Neftegazovoe $i$ gornoe delo, 2015, no. 15, pp. 73-80. DOI: 10.15593/2224-9923/2015.15.8

35. Antonov O.G., Nasybullin A.V., Lifant'ev A.V., Rakhmanov A.R. Ispol'zovanie dannykh indikatornykh issledovanii pri sozdanii postoianno deistvuiushchei geologotekhnologicheskoi modeli [Use of tracer survey data for building a permanently updated geological and reservoir model]. Neftianoe khoziaistvo, 2013, no. 7, pp. 40-42.

36. Chertenkov M.V., Chuiko A.I., Mett D.A. Ispol'zovanie dannykh gidrodinamicheskikh issledovanii dlia postroeniia detal'nykh geologo-gidrodinamicheskikh modelei [Using well test data for detailed geological and hydrodynamic models]. Neftianoe khoziaistvo, 2014, no. 4, pp. 48-50.

37. Zakirov E.S., Indrupskii I.M., Anikeev D.P. Problemy chislennogo modelirovaniia razrabotki mestorozhdenii $\mathrm{s}$ ispol'zovaniem kommercheskikh simuliatorov [Problems of numerical simulation of fields' development using commercial simulation software]. Geologiia, geofizika i razrabotka neftianykh i gazovykh mestorozhdenii, 2016, no. 6, pp. 52-58. 
38. Hørsholt S., Nick H.M., Jørgensen J.B. Oil Production Optimization of Black-Oil Models by Integration of Matlab and Eclipse E300. IFAC-PapersOnLine, 2018, vol. 51, iss. 8, pp. 88-93. DOI: 10.1016/j.ifacol.2018.06.360

39. Stepanov S.V., Pospelova T.A. Novaia kontseptsiia matematicheskogo modelirovaniia dlia priniatiia reshenii po razrabotke mestorozhdenii [New concept of mathematical modeling for making reservoir engineering decisions]. Neftianoe khoziaistvo, 2019 , no. 4, pp. 50-53. DOI: 10.24887/0028-2448-2019-4-50-53

40. Nasybullin A.V., Latifullin F.M., Antonov O.G., Gumarov N.F., Ganiev B.G. Avtomatizatsiia podbora geologo-tekhnicheskikh meropriiatii na postoianno deistvuiushchei geologo-tekhnologicheskoi modeli [Technology for computerized selection of reservoir management technologies by using permanently updated model]. Neftianoe khoziaistvo, 2012, no. 4, pp. 106-107.

41. Nasybullin A.V., Khanipov M.N., Sattarov R.Z. Razvitie tekhnologii sistemnogo vozdeistviia na plast $s$ primeneniem gidrodinamicheskogo modelirovaniia [Development of formation treatment technologies using reservoir simulation studies]. Neftianoe khoziaistvo, 2013, no. 7, pp. 36-39.

42. Kanevskaia R.D. O problemakh modelirovaniia i monitoringa mestorozhdenii na razlichnykh stadiiakh razrabotki [On the problems of modeling and monitoring of deposits at various stages of developmen]. Tekhnologii nefti i gaza, 2015, no. 5, pp. 55-61.

43. Nasybullin A.V., Antonov O.G., Shutov A.A., Rakhmanov A.R., Gumarov N.F., Ganiev B.G. Optimizatsiia sistemy zavodneniia na osnove trekhmernogo geologo-gidrodinamicheskogo modelirovaniia $\mathrm{i}$ iskusstvennogo intellekta [3D reservoir modeling and AI-based optimization of waterflooding system]. Neftianoe khoziaistvo, 2012, no. 7, pp. 14-16.

44. Zhoglo V.G., Demianenko N.A., Khaletskii A.V., Grimus S.I., Vinitskaia N.M., Budnik N.I. Ob adaptatsii geologogidrodinamicheskikh modelei $\mathrm{i}$ ispol'zovanii rezul'tatov modelirovaniia dlia upravleniia razrabotkoi mestorozhdenii Belarusi [On adaptation of geological and hydrodynamic models and using the results of simulation for control of fields development in Belarus]. Neftianoe khoziaistvo, 2012, no. 9, pp. 78-81.

45. Tsepelev V.P., Pislegin M.N., Timchuk A.S. Avtomatizirovannaia adaptatsiia gidrodinamicheskikh modelei $\mathrm{s}$ ispol'zovaniem nastraivaemykh polei koeffitsientov pronitsaemosti [Automaticc history matching of reservoir simulation models with using of permeability fields multiplier tuning]. Neftianoe khoziaistvo, 2011, no. 10, pp. 97-99.

46. Repina V.A., Galkin V.I., Galkin S.V. Primenenie kompleksnogo ucheta petrofizicheskikh kharakteristik pri adaptatsii geologo-gidrodinamicheskikh modelei (na primere vizeiskoi zalezhi Gondyrevskogo mestorozhdeniia nefti) [Complex petrophysical correction in the adaptation of geological hydrodynamic models (on the example of Visean pool of Gondyrev oil field)]. Zapiski Gornogo instituta, 2018, vol. 231, pp. 268-274. DOI: 10.25515/PMI.2018.3.268

\section{Библиографрический список}

1. Потехин Д.В., Путилов И.С., Галкин В.И. Повышение достоверности геологических моделей залежей нефти и газа на основе усовершенствованной технологии многовариантного трехмерного моделирования // Нефтяное хозяйство. - 2014. № 6. - С. 16-19.

2. Путилов И.С., Потехин Д.В. Разработка методики многовариантного 3D-моделирования с контролем качества реализаций для повышения достоверности геологических моделей // Нефтяное хозяйство. - 2015. - № 1. - С. 15-17.

3. Wellmann F., Caumon G. 3-D Structural geological models: Concepts, methods, and uncertainties. - Advances in Geophysics, 2018. - 121 p. DOI: 10.1016/bs.agph.2018.09.001

4. Вопросы качественной оценки геологической модели / А.В. Гетман, В.Л. Киселев, А.С. Алексеев, В.П. Волков, И.Ф. Ишмуратов // Нефтяное хозяйство. - 2013. - № 11. - С. 90-93.
5. 3D Geological Modeling and Its Application under Complex Geological Conditions / S. Yan-lin, Z. Ai-ling, H. Youbin, X. Ke-yan // Procedia Engineering. - 2011. - Vol. 12. P. 41-46. DOI: 10.1016/j.proeng.2011.05.008

6. Creation of 3D Geological Models Using Interpolation Methods for Numerical Modelling / J. Muzik, T. Vondráčková, D. Sitányiová, J. Plachý, V. Nývlt // Procedia Earth and Planetary Science. - 2015. - Vol. 15. - P. 25-30. DOI: $10.1016 /$ j.proeps.2015.08.007

7. Multi-parameter quantitative assessment of 3D geological models for complex fault-block oil reservoirs / T. Xuequn, L. Yunyan, Z. Xiaozhou, L. Jiandang, Z. Rongchen, J. Chao // Petroleum Exploration and Development. - 2019. - Vol. 46. iss. 1. P. 194-204. DOI: 10.1016/S1876-3804(19)30019-9

8. Carmichael T., Ailleres L. Method and analysis for the upscaling of structural data // Journal of Structural Geology. 2016. - Vol. 83. - P. 121-133. DOI: 10.1016/j.jsg.2015.09.002

9. Sharifia M., Kelkar M. Novel permeability upscaling method using Fast Marching Method // Fuel. - 2014. - Vol. 117, part A. - P. 568-578. DOI: 10.1016/j.fuel.2013.08.084

10. Снижение размерности моделей многопластовых залежей с сохранением их геологических особенностей / А.Г. Колягин, В.Л. Терентьев, Е.И. Шевченко, В.В. Денисов, К.М. Федоров // Нефтяное хозяйство. - 2013. - № 9. - С. 40-43.

11. Лобанова О.А., Индрупский И.М. Неравновесные и масштабные эффекты в моделировании фазового поведения углеводородных смесей // Нефтяное хозяйство. - 2012. № 6. - С. 49-53.

12. Amirsardari M., Dabir B., Naderifar A. Development of a flow based dynamic gridding approach for fluid flow modeling in heterogeneous reservoirs // Journal of Natural Gas Science and Engineering. - 2016. - Vol. 31. - P. 715-729. DOI: $10.1016 /$ j.jngse.2016.03.077

13. Ефимов Д.В., Савичев В.И. Опыт практического моделирования свойств пластовых флюидов: от стандартных корреляций к композиционным термодинамическим моделям // Нефтяное хозяйство. - 2012. - № 4. - С. 56-59.

14. Pedersen K., Christensen P., Shaikh J. Phase Behavior of Petroleum Reservoir Fluid. - Boca Raton: CRC Press, 2007. - 465 p.

15. Овчаров В.В. Модификация функций относительных фазовых проницаемостей для регуляризации численного решения задачи вытеснения нефти водой // Нефтяное хозяйство. - 2014. - № 3. - С. 102-105.

16. Pereira G.G. Fluid flow, relative permeabilities and capillary pressure curves through heterogeneous porous media // Applied Mathematical Modelling. - 2019. - Vol. 75. - P. 481-493. DOI: 10.1016/j.apm.2019.05.050

17. Степанов С.В., Глумов Д.Н. Оценка влияния различных подходов к обоснованию начального распределения флюидов и их подвижности на результаты гидродинамического моделирования // Нефтяное хозяйство. 2013. - № 12. - С. 112-116.

18. A new numerical simulator considering the effect of enhanced liquid on relative permeability / S. Wang, C. Yu, G. Sang, Q. Zhao // Journal of Petroleum Science and Engineering. - 2019. Vol. 177. - P. 282-294. DOI: 10.1016/j.petrol.2019.02.053

19. Свалов А.М. Анализ проблем построения кривых капиллярного давления при моделировании пластовых процессов // Нефтяное хозяйство. - 2015. - № 5. - С. 70-73.

20. Обоснование изменения водонасыщенности по высоте залежи нефти и газа при геолого-гидродинамическом моделировании / А.С. Некрасов, Д.В. Потехин, А.В. Шилов, А.В. Габнасыров, М.А. Присяжнюк // Нефтяное хозяйство. 2015. - № 10. - C. 78-81.

21. Jing-qiang L., Chao-mo Z., Zhansong Z. Combine the capillary pressure curve data with the porosity to improve the prediction precision of permeability of sandstone reservoir // Journal of Petroleum Science and Engineering. - 2016. - Vol. 139. P. 43-48. DOI: 10.1016/j.petrol.2015.12.018 
22. Single-and two-phase flow model in low-permeability reservoir / S. Fuquan, S. Xingxing, W. Yong, S. Yeheng // Petroleum. - 2019. - Vol. 5, iss. 2. - P. 183-190. DOI: $10.1016 /$ j.petlm.2018.05.004

23. Сазонов Е.О., Нугаева А.Н., Червякова А.Н. Новые подходы к равновесной инициализации модели BlackOil и обоснованию уровней зеркала свободной воды и поверхности водонефтяного контакта // Нефтяное хозяйство. - 2018. № 6. - C. 70-75. DOI: 10.24887/0028-2448-2018-6-70-75

24. Черемисин Н.А., Бикбулатова Т.Г., Елецкий С.В. Априорный подход к оценке возможности использования гидродинамических моделей на практике при известных ошибках в задании начальных данных // Нефтяное хозяйство. 2013. - № 10. - C. 57-61.

25. Повышение качества геолого-гидродинамического моделирования / К.Е. Закревский, А.В. Аржиловский, А.С. Тимчук, М.А. Грищенко, Т.Г. Бикбулатова // Нефтяное хозяйство. - 2012. - № 10. - С. 44-48.

26. Денисов В.В., Живчук М.В. Экспресс-оценка невязки и ускорение настройки гидродинамической модели // Нефтяное хозяйство. - 2018. - № 11. - С. 100-101. DOI: $10.24887 / 0028-2448-2018-11-100-101$

27. Spilsbury-Schakel J.A. Quality control of static reservoir models // SPE Asia Pacific Oil \& Gas Conference and Exhibition, 11-13 September. - Adelaide, Australia, 2006. DOI: $10.2118 / 101875-\mathrm{MS}$

28. Новый адаптивный подход к геологогидродинамическому моделированию длительно разрабатываемых месторождений и залежей / Е.Н. Тараскин, И.С. Гутман, С.А. Руднев, А.З. Захарян, С.О. Урсегов // Нефтяное хозяйство. - 2017. - № 6. - С. 78-83. DOI: $10.24887 / 0028-2448-2017-6-78-83$

29. Создание и использование постоянно действующей геолого-технологической модели 3-го блока Березовской площади / Р.Р. Ибатуллин, И.М. Бакиров, А.В. Насыбуллин, О.Г. Антонов, А.Р. Рахманов // Нефтяное хозяйство. - 2012. № 2. - C. 54-56.

30. Modelling boreholes in complex heterogeneous aquifers / K.A. Upton, A.P. Butler, C.R. Jackson, M. Mansour // Environmental Modelling \& Software. - 2019. - Vol. 118. - P. 48-60. DOI: $10.1016 /$ j.envsoft.2019.03.018

31. О возможности геологически согласованного уточнения параметров газогидродинамической модели в межскважинном пространстве по данным эксплуатации скважин / Э.С. Закиров, И.М. Ширяев, И.М. Индрупский, О.В. Любимова // Геология, геофизика и разработка нефтяных и газовых месторождений. - 2016. - № 12. - С. 33-40.

32. Технология подготовки, хранения и совместного анализа информации для создания комплексных геологогидродинамических моделей объектов разработки нефтяных месторождений / М.Ш. Магдеев, М.В. Федотов, С.А. Маслов, А.А. Назаров // Геология, геофизика и разработка нефтяных и газовых месторождений. - 2017. - № 10. - С. 17-22.

33. Михайлов Н.Н. Новые направления повышения информативности геолого-гидродинамического моделирования залежи // Нефтяное хозяйство. - 2013. - № 3. - С. 69-73.

34. Повышение эффективности гидродинамического моделирования посредством применения усовершенствованных методик обработки данных гидродинамических исследований скважин (на примере Озерного месторождения) / М.В. Латышева, Ю.В. Устинова, В.В. Кашеварова, Д.В. Потехин // Вестник Пермского национального исследовательского политехнического университета. Геология. Нефтегазовое и горное дело. 2015. - № 15. - C. 73-80. DOI 10.15593/2224-9923/2015.15.8

35. Использование данных индикаторных исследований при создании постоянно действующей геолого-технологической модели / О.Г. Антонов, А.В. Насыбуллин, А.В. Лифантьев, А.Р. Рахманов // Нефтяное хозяйство. - 2013. - № 7. - С. 40-42.

36. Чертенков М.В., Чуйко А.И., Метт Д.А. Использование данных гидродинамических исследований для построения детальных геолого-гидродинамических моделей // Нефтяное хозяйство. - 2014. - № 4. - С. 48-50.

37. Закиров Э.С., Индрупский И.М., Аникеев Д.П. Проблемы численного моделирования разработки месторождений с использованием коммерческих симуляторов // Геология, геофизика и разработка нефтяных и газовых месторождений. - 2016. - № 6. - С. 52-58.

38. Hørsholt S., Nick H.M., Jørgensen J.B. Oil Production Optimization of Black-Oil Models by Integration of Matlab and Eclipse E300 // IFAC-PapersOnLine. - 2018. - Vol. 51, iss. 8. P. 88-93. DOI: 10.1016/j.ifacol.2018.06.360

39. Степанов С.В., Поспелова Т.А. Новая концепция математического моделирования для принятия решений по разработке месторождений // Нефтяное хозяйство. - 2019. № 4. - C. 50-53.

40. Автоматизация подбора геолого-технических мероприятий на постоянно действующей геологотехнологической модели / А.В. Насыбуллин, Ф.М. Латифуллин, О.Г. Антонов, Н.Ф. Гумаров, Б.Г. Ганиев // Нефтяное хозяйство. 2012. - № 4. - C. 106-107.

41. Насыбуллин А.В., Ханипов М.Н., Саттаров Р.3. Развитие технологий системного воздействия на пласт с применением гидродинамического моделирования // Нефтяное хозяйство. 2013. - № 7. - С. 36-39.

42. Каневская Р.Д. О проблемах моделирования и мониторинга месторождений на различных стадиях разработки // Технологии нефти и газа. - 2015. - № 5. - С. 55-61.

43. Оптимизация системы заводнения на основе трехмерного геолого-гидродинамического моделирования и искусственного интеллекта / А.В. Насыбуллин, О.Г. Антонов, А.А. Шутов, А.Р. Рахманов, Н.Ф. Гумаров, Б.Г. Ганиев // Нефтяное хозяйство. - 2012. - № 7. - С. 14-16.

44. Об адаптации геолого-гидродинамических моделей и использовании результатов моделирования для управления разработкой месторождений Беларуси / В.Г. Жогло, Н.А. Демяненко, А.В. Халецкий, С.И. Гримус, Н.М. Виницкая, Н.И. Будник // Нефтяное хозяйство. - 2012. - № 9. - С. 78-81.

45. Цепелев В.П., Пислегин М.Н., Тимчук А.С. Автоматизированная адаптация гидродинамических моделей с использованием настраиваемых полей коэффициентов проницаемости // Нефтяное хозяйство. - 2011. - № 10. - С. 97-99.

46. Репина В.А., Галкин В.И., Галкин С.В. Применение комплексного учета петрофизических характеристик при адаптации геолого-гидродинамических моделей (на примере визейской залежи Гондыревского месторождения нефти) // Записки Горного института. - 2018. - Т. 231. - С. 268-274. DOI: 10.25515/PMI.2018.3.268

Please cite this article in English as:

Smetkina M.A., Melkishev O.A., Prisyazhnyuk M.A. Refining the Values of Permeability when Adapting the Hydrodynamic Model. Perm Journal of Petroleum and Mining Engineering, 2020, vol.20, no.3, pp.223-230. DOI: 10.15593/2712-8008/2020.3.3

Просьба ссылаться на эту статью в русскоязычных источниках следующим образом:

Сметкина М.А., Мелкишев О.А., Присяжнюк М.А. Уточнение значений проницаемости при адаптации гидродинамической модели // Недропользование. - 2020. - Т.20, №3. - С.223-230. DOI: 10.15593/2712-8008/2020.3.3 